\title{
Relative contribution of rainfall and coconut hybrids to the abundance and composition of the Auchenorrhyncha community as potential vectors of phytoplasmas in the state of Sergipe, Brazil
}

\author{
Flaviana G. da Silva*, Eliana M. dos Passos ${ }^{\dagger}$, Leandro E. C. Diniz ${ }^{\dagger}$, Marcelo F. Fernandes* ${ }^{* \dagger}$, Charles R. Bartlett", \\ Michel Dollet ${ }^{\S}$ and Adenir V. Teodoro*† \\ * Department of Agronomic Engineering, Universidade Federal de Sergipe, São Cristovão, Avenida Marechal Rondon, 49100-000, Sergipe, Brazil, \\ ${ }^{\dagger}$ Embrapa Tabuleiros Costeiros, Avenida Beira Mar, Aracaju, Avenida Beira Mar, Sergipe 44, Brazil, ${ }^{\ddagger}$ Department of Entomology and Wildlife Ecology, \\ University of Delaware, South College Avenue, Newark, DE 19716-2160, U.S.A. and ${ }^{\S}$ CIRAD, UMR IPME, Avenue Agropolis, Montpellier 44, France
}

\begin{abstract}
The quarantine disease Lethal Yellowing (LY) is currently the main threat to coconut cultivation in Brazil. LY is caused by phytoplasmas and is transmitted by Haplaxius crudus (Hemiptera: Cixiidae), although other planthoppers/leafhoppers could be involved.

2 We assessed the Auchenorrhyncha community composition on various coconut hybrids, including association with parental and nonparental dwarf coconut accessions.

3 The Auchenorrhyncha were trapped in 2016 between the dry and rainy seasons (March and April), in the rainy season (July and August) and in the dry season (November and December).

4 Oecleus sergipensis (Hemiptera: Cixiidae) accounted for $73 \%$ of the individuals, with a predominance at the dry-to-rainy season transition. Curtara samera (Hemiptera: Cicadellidae) was the best-represented species on the hybrids Brazilian Green Dwarf $\times$ Brazilian Tall - Praia do Forte, Brazilian Green Dwarf $\times$ Vanuatuan Tall and Malayan Yellow Dwarf $\times$ West African Tall. Oecleus sergipensis was the best-represented species on the hybrids Malayan Red Dwarf $\times$ Tagnanan Tall, Malayan Red Dwarf $\times$ Vanuatuan Tall and Malayan Yellow Dwarf $\times$ Brazilian Tall - Praia do Forte.

5 Individuals of a species of Cenchreini and Omolicna nigripennis (Hemiptera: Derbidae) increase in the rainy season; Balclutha sp. (Hemiptera: Cicadellidae) and Cedusa sp. (Hemiptera: Derbidae) are prevalent in the transition period between the dry and rainy seasons. Knowledge about potential Auchenorrhyncha phytoplasma vectors on coconut hybrids could contribute to the development of strategies for use in breeding programmes for coconut LY prevention.
\end{abstract}

Keywords Cixiidae, Cocos nucifera, hybrids, lethal yellowing, Oecleus sergipensis.

\begin{abstract}
Introduction
Lethal Yellowing syndromes of coconut are highly devastating diseases, affecting coconut cultivation and 38 palm species worldwide. They are caused by phytoplasmas. In Florida, Central America and the Caribbean, phytoplasmas of the group 16S rIV are responsible for the declines in local lethal palm. The most prevalent form is known as 'Lethal Yellowing' (LY) (Harrison

Correspondence: Flaviana G. da Silva. Tel.: +55 83998022369; e-mail: flavianagoncalves.16@hotmail.com
\end{abstract}

et al., 2002; Harrison et al., 2008). No efficient curative control methods for these diseases are known and, within 3-6 months after the appearance of the first symptoms, all attacked plants die, causing the complete destruction of the plantation (McCoy et al., 1983).

Lethal palm declines also occur in some countries of North and Central America, Africa, Caribbean and Oceania (Dollet et al., 2009; Harrison et al., 2014; Gurr et al., 2016). They are quarantine diseases that still remain undetected in Brazil. Nevertheless, they pose a serious threat to Brazilian coconut cultivation because the country is the fourth largest producer of 
coconut worldwide and the top producer of coconut water (FAO, 2017). Aside from dwarf and tall coconut varieties, dwarf $\times$ tall coconut hybrids also are widely cultivated for their commercial utility in the production of copra/oil, fibres and coconut water (Siqueira et al., 2002).

Species of auchenorrhynchous Hemiptera are vectors of phytoplasmas associated with diseases in crops of high economic value, such as corn, grapes, fruit trees and vegetables. This has promoted the targeted investigation of Fulgoroidea (e.g. Cixiidae and Derbidae; 'planthoppers') and deltocephaline Cicadellidae ('leafhoppers') as potential plant pathogen vectors. These planthoppers and leafhoppers have a feeding habit restricted to the phloem sap where phytoplasmas multiply, characterizing them as potential vectors of these pathogens (Weintraub \& Beanland, 2006). In Florida, the planthopper Haplaxius crudus (Van Duzee) (Hemiptera: Cixiidae) is known as a vector of the $16 \mathrm{~S}$ rIV phytoplasmas associated with LY (Howard et al., 1983). Despite several years of research, the vectors of other lethal palm declines in East and West Africa remain unknown (Mpunami et al., 2000; Philippe et al., 2009). Moreover, some of the research has been limited to testing insects for the presence of pathogens (Mpunami et al., 2000). A positive insect confirms that it has fed on an infected plant, although it says nothing about that the ability of the insect to transmit the pathogens to a healthy plant.

The dynamics of an insect community are influenced by the abiotic and biotic factors that comprise the environmental conditions. The main factors responsible for changes in population numbers, which can contribute significantly to an increase or decrease in the number of individuals, are rainfall, temperature and relative humidity (Win et al., 2011).

Accordingly, the present study aimed to survey and analyze the Auchenorrhyncha community composition of potential phytoplasma vectors of LY in dwarf $\times$ tall coconut hybrids, including parent accessions of dwarf and nonparent coconut, in different seasons in Brazil.

\section{Materials and methods}

\section{Sampling site}

Auchenorrhyncha were collected from six dwarf $\times$ tall coconut hybrids in the transition between dry and rainy seasons (March: $70 \mathrm{~mm}$ rain, $30^{\circ} \mathrm{C}$; April: $56 \mathrm{~mm}$ rain, $29^{\circ} \mathrm{C}$ ); rainy season (July: $75 \mathrm{~mm}$ rain, $29.7^{\circ} \mathrm{C}$; August: $52 \mathrm{~mm}$ rain $29.8^{\circ} \mathrm{C}$ ); and in the dry season (November: $0 \mathrm{~mm}$ rain $33^{\circ} \mathrm{C}$; December: $0 \mathrm{~mm}$ rain, $\left.32.3^{\circ} \mathrm{C}\right)$ of 2016 in an experimental field $(-10.54352$, -36.62632) of Embrapa Tabuleiros Costeiros in the municipality of Itaporanga D'Ajuda, located in the northeastern Brazilian state of Sergipe. The climate of Itaporanga D'Ajuda is tropical rainy with dry summers, in accordance with Köppen's classification (Peel et al., 2007). The mean monthly rainfall and temperature of the study period were measured at a meteorological station installed in the experimental area, and field data were provided by the Brazilian Center for Weather Forecasting and Climate Studies, respectively.

\section{Coconut varieties and hybrids}

The coconut hybrids evaluated were: BGD $\times$ BRT (Brazilian Green Dwarf $\times$ Brazilian Tall - Praia do Forte); MYD $\times$ BRT
(Malayan Yellow Dwarf $\times$ Brazilian Tall - Praia do Forte); BGD $\times$ VTT (Brazilian Green Dwarf $\times$ Vanuatu Tall); MYD $\times$ WAT (Malayan Yellow Dwarf $\times$ West African Tall); MRD $\times$ VTT (Malayan Red Dwarf $\times$ Vanuatu Tall); and MRD $\times$ TAG (Malayan Red Dwarf $\times$ Tagnanan Tall), which were planted in an area previously used for the evaluation of hybrids of coconut trees from different countries (Batugal et al., 2005). The coconut hybrids were 14 years old, spaced $8.5 \times 8.5 \mathrm{~m}$, and arranged in a randomized block design with five replications and 12 hybrid trees per replication. During the samplings period, no cultural practices other than mechanical weeding were employed in the coconut plantation.

\section{Auchenorrhyncha collection}

Monthly collections were carried out using double-sided yellow sticky traps $(8.5 \times 11 \mathrm{~cm}$; ISCA Technologies, Inc., Riverside, California), placed on the leaves of three plants per replication of each coconut hybrid (i.e. 15 traps per hybrid). The traps were collected 15 days after installation in each sampling month, and the Auchenorrhyncha were removed with the help of a solvent (Tira Cola; Allchem Química, Uruguay).

Auchenorrhyncha were identified at the family and subfamily levels, based on morphological characteristics and dichotomous keys (Triplehorn \& Johnson, 2011; Grazia et al., 2012). Thereafter, specimens were sent to taxonomic specialists for identification to the lowest possible level (targeting species level), based on specialized technical references for each taxonomic group. Representative specimens were deposited in the Entomological Collection, University of Delaware, Department of Entomology and Wildlife Ecology, Newark, Delaware, U.S.A., and the Department of Zoology, Federal University of Rio de Janeiro, Brazil.

\section{Statistical analysis}

Changes in the composition of the Auchenorrhyncha community were modelled by multivariate classification and regression tree analysis (MCRA) (De'ath, 2002), using the total rainfall and mean temperature values of 1, 2 and 3 months prior to the samplings, and the hybrids as explanatory variables. This analysis explains the variation in a multivariate response variable as a function of categorical and quantitative explanatory variables (De'ath, 2002). Based on all data represented by a single node at the top, the tree is amplified by repeated binary partitioning of the response variable data. Each partition is defined by a simple rule, based on a single explanatory variable. The explanatory variable and its respective levels or classes used for each data partition are selected among all available combinations because they result in the smallest sum of squares within the two nodes derived from the partition. The partitioning procedure is continued until the tree is sufficiently large for pruning to an appropriate size (number of end nodes). The tree size for interpretation was determined to ensure the smallest minimum relative error at highest frequency in a series of 20 cross-validations, each repeated 10 times (Breiman et al., 1984; De'ath, 2002). For a new partition, the criterion selected was that each new node to be generated should be based on at least three observations. The tree diagram represents all partitioning rules used to separate the different nodes. 
For this analysis, a library of routines in a univariate regression tree ( $\mathrm{T}$. Therneau, unpublished data) was extended by the inclusion of additional $\mathrm{C}$ routines for the implementation of multivariate regression tree analysis (De'ath, 2002). S-PLUS, version 4.0 (Mathsoft Inc., Cambridge, Massachusetts) was used for the analyses. Prior to the analysis, the count of each species was relativized by the sum of counts of all species within each sample.

Indicator species analysis was used to identify the typical species of each intermediate and terminal node of the MCRA (Dufrêne \& Legendre, 1997). The method proposed by these authors calculates an indicator value (IV) for each species, which describes the degree of association of this species to a given condition. In this case, each terminal node of the MCRA was treated as a condition. The indicator value, calculated as the product between the relative abundance (RA) and relative frequency (RF), is assigned to each species and condition evaluated. Relative abundance is expressed as the proportional abundance of a particular species, under a given condition, relative to the abundance of this same species under all evaluated conditions. The relative frequency describes the proportion of samples under a particular condition containing a particular species. The Monte Carlo test, employing 5000 runs with randomized data, was used to test the null hypothesis that the IV obtained with the real data is not greater than that obtained randomly (i.e. that the species has no indicator value). For this analysis, the species counts were processed without relativizing, using PC-ORD 6 (McCune \& Mefford, 2011).

Pearson's correlation analysis was performed between individuals of the most abundant Auchenorrhyncha species caught on hybrids and parent and nonparent dwarf coconut accessions, with a total of 12 observations per hybrid group with the same parent dwarf coconut, using an EXCEL spreadsheet (Microsoft Corp., Redmond, Washington). The numbers of auchenorrynchos collected from the parent and nonparent dwarf coconut (i.e. Brazilian Green Dwarf Jequi - BGDJ; Cameroon Red Dwarf - CRD; Malayan Red Dwarf - MRD; Brazilian Red Dwarf Gramame - BRDG; Brazilian Yellow Dwarf Gramame - BYDG; and Malayan Yellow Dwarf - MYD) used in the correlation with the hybrids were obtained in a previous study (Silva et al., 2018), which was carried out in the same seasons as the survey of the Auchenorrhyncha community on hybrid coconuts in the experimental field of Itaporanga D'Ajuda. Parental dwarf coconut means that there is a dwarf parent in the composition of the hybrid, whereas the nonparent dwarf is not related to any of the varieties that make up the hybrid.

\section{Results}

\section{Auchenorrhyncha survey}

In total, 1153 insects belonging to seven families of Auchenorrhyncha (Cixiidae, Cicadellidae, Derbidae, Membracidae, Delphacidae, Flatidae and Dictyopharidae) were captured on sticky cards places in the six dwarf $\times$ tall coconut hybrids. Seven families were represented by 30 Auchenorrhyncha species, of which Oecleus sergipensis Bartlett (Cixiidae), Curtara samera DeLong \& Freytag, Balclutha sp. (Cicadellidae), Cenchreini sp., Omolicna nigripennis Caldwell, Cedusa sp. (Derbidae) and Erechtia gibbosa (DeGeer) (Membracidae) were the most abundant, representing $81 \%$ of individuals collected (Table 1). Delphacidae, Flatidae and Dictyopharidae were represented only by one individual in each family, respectively.

With respect to seasonality, the highest number of Auchenorrhyncha (272 individuals) was captured in the transition period between the dry and rainy seasons in March, and the lowest number of Auchenorrhyncha was captured in the rainy season in July (56 individuals). With a total of 679 individuals, O. sergipensis was the most abundant species in the present study, accounting for $73 \%$ of the collected Auchenorrhyncha. The lowest number of individuals of this species was counted in July (fiindividuals) and the highest in March (214 individuals), in the dry-to-rainy season transition.

Regarding the impact of coconut varieties and hybrids, the highest number of Auchenorrhyncha (219 individuals) was captured on hybrid BGD $\times$ BRT, and the lowest number $(105$ individuals) on MYD $\times$ WAT. The same pattern was found for $O$. sergipensis (Table 1). This pattern was driven by the occurrence of $O$. sergipensis.

The multivariate regression and classification model generated a tree with five terminal nodes, explaining $77 \%$ of the data variability for the Auchenorrhyncha community composition, of which $69 \%$ was explained by cumulative bimonthly precipitation (Bp) prior to samplings and $8 \%$ by coconut hybrids (Fig. 1).

Two distinct communities were observed in samplings with Bp $<52 \mathrm{~mm}$ and Bp between $52 \mathrm{~mm}$ and $119.87 \mathrm{~mm}$, with no differentiation among the hybrids. Species indicator analysis indicated E. gibbosa, with an indicator value of $27(P=0.325)$, as the only typical species when $\mathrm{Bp}<52 \mathrm{~mm}$ (Table 2). At Bp between 52 and $119 \mathrm{~mm}$, the typical species were $C$. samera $(\mathrm{IV}=71, P=0.008)$, Balclutha sp. $(\mathrm{IV}=67, P=0.001)$ and Cedusa sp. (IV=67, $P=0.001)$. Erechtia gibbosa was observed only in the dry season (relative abundance $=100 \%$, relative frequency $=33 \%$ at $\mathrm{Bp}<52 \mathrm{~mm}$ ). Cedusa sp. and Balclutha $\mathrm{sp}$. occurred exclusively at Bp between 52 and $119 \mathrm{~mm}$ ( $\mathrm{RA}=100 \%, \mathrm{RR}=67 \%$ at $52 \mathrm{~mm}<\mathrm{Bp}<119 \mathrm{~mm}$ ). Curtara samera relative abundance was $77 \%$ and relative frequency $92 \%$ at $52 \mathrm{~mm}<\mathrm{Bp}<119 \mathrm{~mm}$.

At Bp $>119 \mathrm{~mm}$, the Auchenorrhyncha community composition of the hybrids BGD $\times$ BRT, BGD $\times$ VTT and MYD $\times$ WAT differed from those of MRD $\times$ TAG, MRD $\times$ VTT and $\mathrm{MYD} \times \mathrm{BRT}$. A comparison of these two groups indicated C. samera as the only typical species (IV $=76, P<0.069)$ of the first group, and $O$. sergipensis as a typical species of the second group (IV $=94, P=0.014$ ). In their respective hybrid groups, both species were recorded in all observations $(\mathrm{RF}=100 \%)$. Some $76 \%$ of individuals of $C$. samera and $94 \%$ of $O$. sergipensis occurred in their respective preferred hybrid group (Table 2).

The Auchenorrhyncha community composition of the hybrid group BGD $\times$ BRT, BGD $\times$ VTT and MYD $\times$ WAT did not differ under different $\mathrm{Bp}$. However, in the hybrid group MRD $\times$ TAG, $\mathrm{MRD} \times \mathrm{VTT}$ and MYD $\times \mathrm{BRT}$, two relatively distinct communities were observed as a result of variations in Bp. Curtara samera occurred exclusively and in all observations of periods with $\mathrm{Bp}>182 \mathrm{~mm}$. The same was observed for Balclutha $\mathrm{sp}$. in periods with Bp between 119 and $182 \mathrm{~mm}$. It was found that the two MYD hybrids differed from each other for this composition. On MYD $\times$ BRT, an enriched composition of $O$. sergipensis was observed grouped with hybrids derived from MRD, whereas 
Table 1 Total number of individuals of the most abundant Auchenorrhyncha species on dwarf $\times$ tall coconut hybrids

\begin{tabular}{|c|c|c|c|c|c|c|c|c|c|}
\hline \multirow[b]{2}{*}{$\begin{array}{l}\text { Average rainfall } \\
\text { and temperature }\end{array}$} & \multirow{2}{*}{$\begin{array}{l}\text { Family } \\
\text { Hybrids }\end{array}$} & \multirow{2}{*}{$\begin{array}{l}\text { Cixiidae } \\
\text { Oecleus } \\
\text { sergipensis }\end{array}$} & \multicolumn{3}{|c|}{ Cicadellidae } & \multicolumn{2}{|l|}{ Derbidae } & \multicolumn{2}{|c|}{ Membracidae } \\
\hline & & & $\begin{array}{l}\text { Curtara } \\
\text { samera }\end{array}$ & Balclutha sp. & Cenchreini sp. & $\begin{array}{l}\text { Omolicna } \\
\text { nigripennis }\end{array}$ & Cedusa sp. & $\begin{array}{l}\text { Erechtia } \\
\text { gibbosa }\end{array}$ & Total \\
\hline \multirow[t]{6}{*}{$\operatorname{March}\left(70 \mathrm{~mm}, 30^{\circ} \mathrm{C}\right)$} & $\mathrm{BGD} \times \mathrm{BRT}$ & 46 & 5 & 1 & 0 & 0 & 2 & 0 & 54 \\
\hline & MYD $\times B R T$ & 39 & 4 & 0 & 0 & 0 & 2 & 0 & 45 \\
\hline & $\mathrm{BGD} \times \mathrm{VTT}$ & 24 & 2 & 0 & 0 & 0 & 5 & 0 & 31 \\
\hline & MYD $\times$ WAT & 30 & 8 & 5 & 0 & 0 & 4 & 0 & 47 \\
\hline & $\mathrm{MRD} \times \mathrm{VTT}$ & 44 & 1 & 3 & 2 & 1 & 3 & 0 & 54 \\
\hline & $M R D \times T A G$ & 31 & 5 & 3 & 0 & 0 & 2 & 0 & 41 \\
\hline \multirow[t]{6}{*}{ April $\left(56 \mathrm{~mm}, 29^{\circ} \mathrm{C}\right)$} & $\mathrm{BGD} \times \mathrm{BRT}$ & 20 & 7 & 3 & 0 & 0 & 1 & 0 & 31 \\
\hline & MYD $\times B R T$ & 18 & 6 & 0 & 0 & 0 & 0 & 0 & 24 \\
\hline & $\mathrm{BGD} \times \mathrm{VTT}$ & 7 & 6 & 1 & 0 & 0 & 0 & 0 & 14 \\
\hline & MYD $\times$ WAT & 9 & 0 & 0 & 0 & 0 & 2 & 0 & 11 \\
\hline & $\mathrm{MRD} \times \mathrm{VTT}$ & 19 & 4 & 1 & 0 & 3 & 0 & 0 & 27 \\
\hline & $M R D \times T A G$ & 9 & 2 & 2 & 0 & 1 & 0 & 0 & 14 \\
\hline \multirow[t]{6}{*}{ July $\left(75 \mathrm{~mm}, 29.7^{\circ} \mathrm{C}\right)$} & $\mathrm{BGD} \times \mathrm{BRT}$ & 1 & 9 & 0 & 1 & 1 & 1 & 0 & 13 \\
\hline & MYD $\times B R T$ & 2 & 7 & 0 & 3 & 0 & 2 & 0 & 14 \\
\hline & $B G D \times V T T$ & 0 & 2 & 0 & 0 & 1 & 1 & 0 & 4 \\
\hline & MYD $\times$ WAT & 0 & 2 & 1 & 0 & 1 & 1 & 0 & 5 \\
\hline & $\mathrm{MRD} \times \mathrm{VTT}$ & 1 & 5 & 0 & 2 & 0 & 0 & 0 & 8 \\
\hline & $M R D \times T A G$ & 1 & 5 & 0 & 3 & 3 & 0 & 0 & 12 \\
\hline \multirow[t]{6}{*}{ August $\left(52 \mathrm{~mm}, 29.8^{\circ} \mathrm{C}\right)$} & $\mathrm{BGD} \times \mathrm{BRT}$ & 1 & 16 & 0 & 4 & 4 & 1 & 0 & 26 \\
\hline & MYD $\times B R T$ & 12 & 0 & 1 & 0 & 0 & 0 & 0 & 13 \\
\hline & $B G D \times V T T$ & 0 & 22 & 0 & 3 & 4 & 1 & 0 & 30 \\
\hline & MYD $\times$ WAT & 0 & 3 & 0 & 3 & 0 & 0 & 0 & 6 \\
\hline & $\mathrm{MRD} \times \mathrm{VTT}$ & 7 & 0 & 1 & 4 & 4 & 1 & 0 & 17 \\
\hline & $M R D \times T A G$ & 7 & 0 & 1 & 4 & 4 & 1 & 0 & 17 \\
\hline \multirow[t]{6}{*}{ November $\left(0 \mathrm{~mm}, 33^{\circ} \mathrm{C}\right)$} & $\mathrm{BGD} \times \mathrm{BRT}$ & 63 & 2 & 0 & 0 & 0 & 0 & 0 & 65 \\
\hline & MYD $\times B R T$ & 23 & 1 & 0 & 0 & 0 & 0 & 0 & 24 \\
\hline & $\mathrm{BGD} \times \mathrm{VTT}$ & 24 & 0 & 0 & 0 & 0 & 0 & 1 & 25 \\
\hline & MYD $\times$ WAT & 12 & 0 & 0 & 0 & 1 & 0 & 0 & 13 \\
\hline & $\mathrm{MRD} \times \mathrm{VTT}$ & 35 & 1 & 0 & 0 & 0 & 0 & 0 & 36 \\
\hline & $M R D \times T A G$ & 23 & 0 & 0 & 0 & 0 & 0 & 1 & 24 \\
\hline \multirow[t]{7}{*}{ December $\left(0 \mathrm{~mm}, 32.3^{\circ} \mathrm{C}\right)$} & $\mathrm{BGD} \times \mathrm{BRT}$ & 27 & 2 & 0 & 0 & 1 & 0 & 0 & 30 \\
\hline & MYD $\times$ BRT & 42 & 2 & 0 & 0 & 0 & 0 & 0 & 44 \\
\hline & $\mathrm{BGD} \times \mathrm{VTT}$ & 21 & 4 & 0 & 0 & 0 & 0 & 2 & 27 \\
\hline & MYD $\times$ WAT & 22 & 0 & 0 & 0 & 0 & 0 & 1 & 23 \\
\hline & $\mathrm{MRD} \times \mathrm{VTT}$ & 29 & 2 & 0 & 0 & 0 & 0 & 4 & 35 \\
\hline & $M R D \times T A G$ & 30 & 1 & 0 & 0 & 0 & 0 & 0 & 31 \\
\hline & Total & 679 & 136 & 23 & 29 & 29 & 30 & 9 & 935 \\
\hline
\end{tabular}

${ }^{a}$ BGD $\times$ BRT (Brazilian Green Dwarf × Brazilian Tall - Praia do Forte), MYD ×BRT (Malayan Yellow Dwarf × Brazilian Tall - Praia do Forte), BGD $\times$ VTT (Brazilian Green Dwarf $\times$ Vanuatuan Tall); MYD $\times$ WAT (Malayan Yellow Dwarf $\times$ West African Tall); MRD $\times$ VTT (Malayan Red Dwarf $\times$ Vanuatuan Tall); and MRD $\times$ TAG (Malayan Red Dwarf $\times$ Tagnanan Tall).

MYD $\times$ WAT, with the lowest mean abundance of $O$. sergipensis, was grouped with the hybrids derived from BGDJ. For the tall parent coconut, the communities on BRT-derived hybrids were similar, also with more $O$. sergipensis individuals (Table 2).

The temporal correlation of MRD and its hybrids $(\mathrm{MRD} \times \mathrm{VTT}$ and $\mathrm{MRD} \times \mathrm{TAG})$ with $O$. sergipensis populations was high $(r=0.74, P<0.01)$, in contrast to that observed for BGDJ $(r=0.39, P<0.10)$ and MYD $(r=-0.37, P<0.10)$ and their respective hybrids. Correlations between MRD with parental hybrids and the other nonparental dwarf coconut accessions with MYD $(r=-0.40, P<0.05)$ and BGDJ $(r=0.54$; $P<0.05$ ) were not significant (Fig. 2).

\section{Discussion}

The composition of the Auchenorrhyncha community on different coconut hybrids in the state of Sergipe, Brazil, was influenced mainly by rainfall, followed by the identity of the coconut hybrids. Auchenorrhyncha that are potential phytoplasma vectors of coconut LY were represented by the family Cixiidae, especially $O$. sergipensis as the most abundant, followed by the subfamily Deltocephalinae (Cicadellidae) and possibly the family Derbidae.

Some Auchenorrhyncha species are vectors of phytoplasma causing diseases in agricultural crops and ornamental plants, mainly Cixiidae and Deltocephalinae species (Howard et al., 1983; Weintraub \& Beanland, 2006; Bressan et al., 2009; Dakhil et al., 2011; Cvrkovic et al., 2014; Chuche et al., 2016). Also, a derbid species was claimed to be vector of the pathogen that causes Kerala Root Wilt of coconut in India (Edwin \& Mohankumar, 2007a; Edwin \& Mohankumar, 2007b; Rajan, 2013), in addition to the first recognized vector in the family Tingidae, Stephanitis typica (Distant) (Heteroptera, not Auchenorrhynhca) (Mathen et al., 1987; Mathen et al., 1990). Knowledge about 


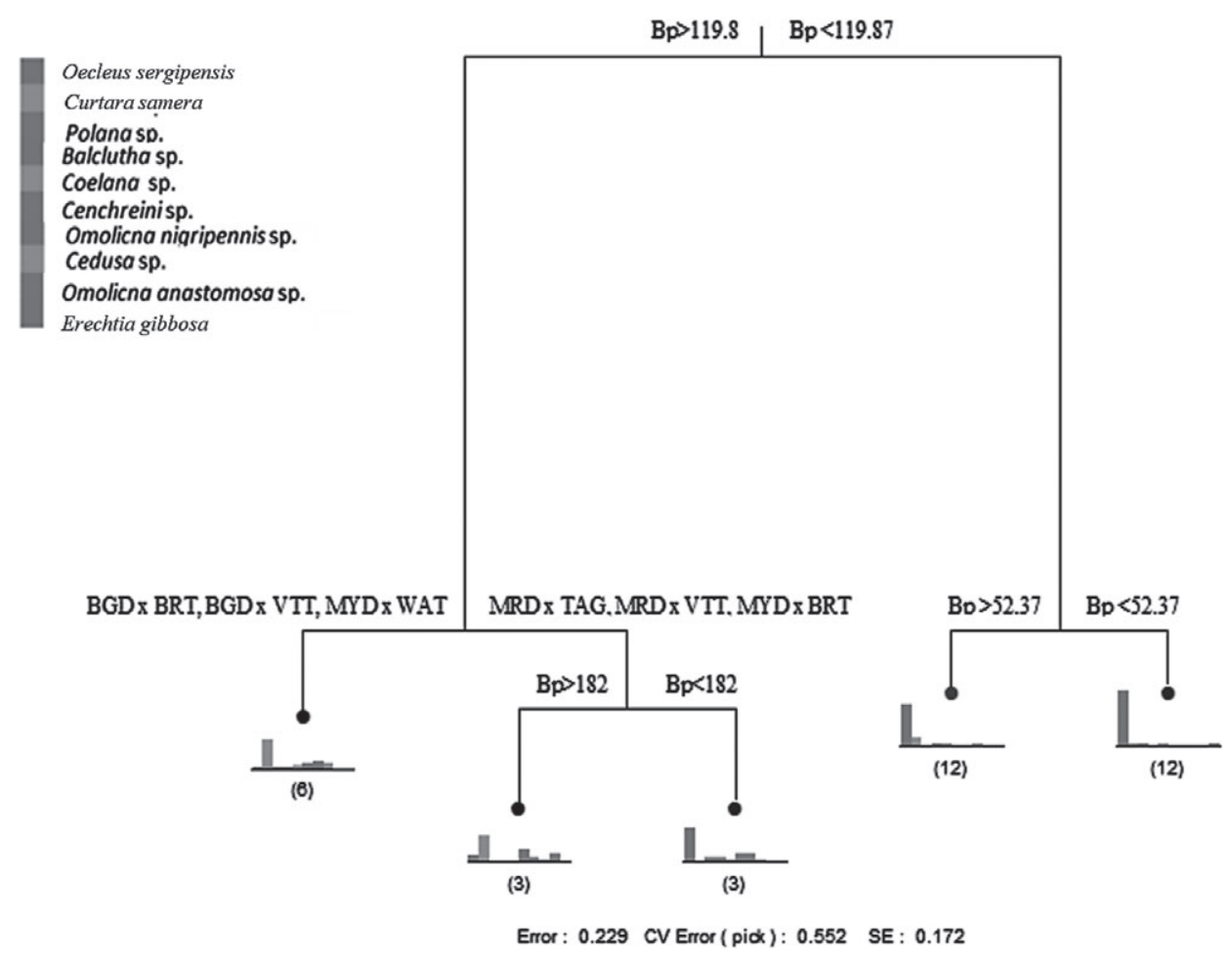

Figure 1 Tree regression model of the Auchenorrhyncha community as affected by bimonthly precipitation (Bp) and coconut hybrids. The length of the vertical tree branches is proportional to the variability explained by the explanatory variables used in each partition.

insect communities is extremely important for risk management of pest introduction and the dispersion and implementation of appropriate site-specific phytosanitary measures (Melo et al., 2008).

The LY vector $H$. crudus (Hemiptera: Fulgoroidea) was found in Brazil in the 1980/90s, in an oil palm plantation in Belem, Para State (Louise, 1990; Celestino Filho et al., 1993). A recent survey in Para in 2017 confirmed the presence of this insect species on oil palms and coconuts in the surroundings of Belem (F. G. Silva, unpublished data). In our studies in Sergipe, no H. crudus specimens were found, although a high number of individuals of a new species of cixiid in the genus Oecleus Stål, belonging to the same family and tribe as $H$. crudus (Cixiidae: Oecleini), was captured. This new species, O. sergipensis, was described recently (Bartlett et al., 2018), and is a potential vector of phytoplasmas, including coconut LY phytoplasmas. Oecleus species also are reported from coconut plantations in Mexico. Oecleus snowi Ball was suspected as a potential possible vector of LY in a LY-affected coconut plantation of Tabasco State. In this plantation, several cixiids were present: Haplaxius skarphion (Kramer), Haplaxius caldwelli (Kramer) and $H$. crudus. However all attempts to transmit LY to healthy coconuts in cages with captured Haplaxius spp. from this LY affected plantation failed despite several thousands of insects being released in cages with coconuts (J.-L. Dzido, C. F. Ortiz Garcia, C. Oropeza, S. Fabre and M. Dollet, unpublished data). This raised the question of the possible existence of other vectors of LY in the Caribbean and Central America, as already suspected (Dollet et al., 2010).
Among the Deltocephalinae collected in the present study, Balclutha spp. are considered as potential vectors of phytoplasmas. Some species of Balclutha tested positive for almond witches-broom phytoplasma in Lebanon (Dakhil et al., 2011). Phytoplasmas associated with sugarcane white leaf disease were detected by a polymerase chain reaction (PCR) in two species of Balclutha in northeastern Thailand (Hanboonsong et al., 2006) and a new phytoplasma associated with periwinkle leaf yellowing disease in Taiwan was identified by PCR in some Balclutha species (Chen et al., 2011). However, no experimental transmission was obtained with these species of leafhoppers. Positive insects show that the individuals fed on an infected plant, although they indicate nothing about the potential to transmit the pathogen.

We collected specimes of the derbid genus Cedusa sp. a difficult genus with 16 species recorded from Brazil among 100+ Neotropical species (Flynn \& Kramer, 1983; Kramer, 1986). The species found here may be Cedusa yipara (Kramer) and/or Cedusa yowza (Kramer) because both these species have been found in recent Auchenorrhyncha sampling from palm species in Brazil (F. G. Silva, unpublished data). In Jamaica, Cedusa sp. was suspected to be a putative vector of LY (Brown et al., 2006), although no positive transmissions were obtained, only insects positive for the pathogens by molecular analysis. Another derbid belonging to a new genus and species of the tribe Cenchreini was also collected. It is similar to Omolicna but differs from that genus both in head and genitalic features. Omolicna has been detected on palms and was suggested as a potential vector of phytoplasmas (Segarra-Carmona et al., 2013; Halbert et al., 2014); however, no positive transmissions have been obtained to 


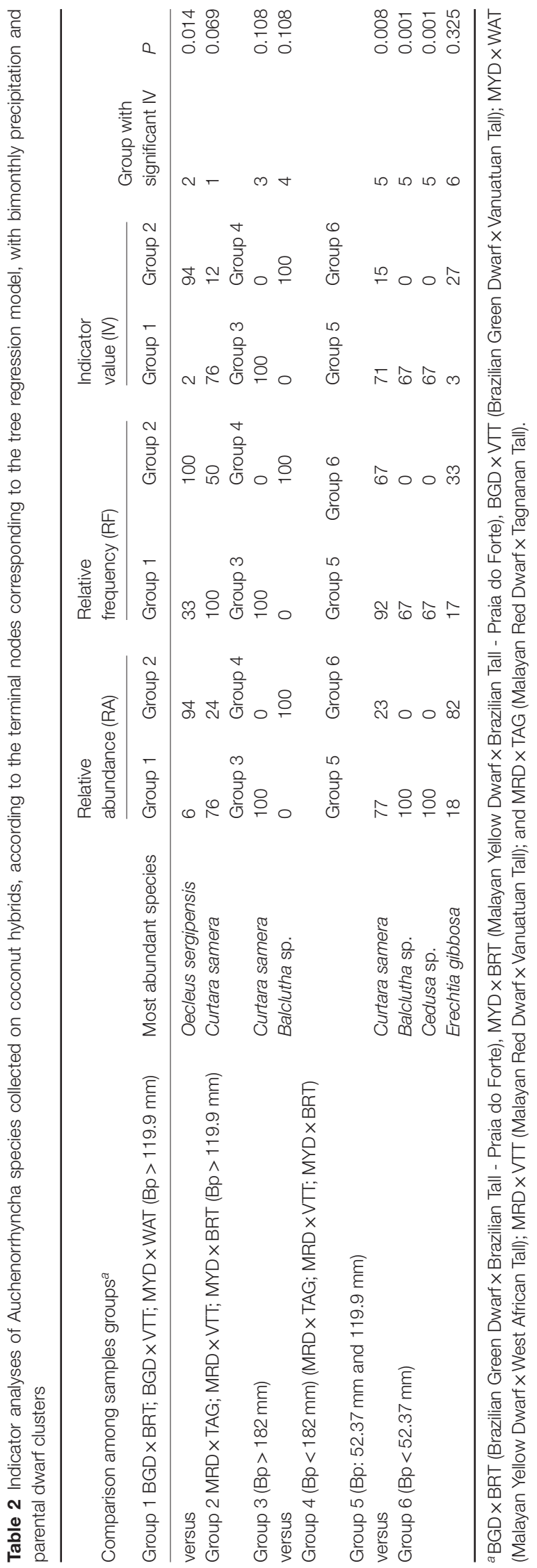

date. The derbid Diostrombus mkurangai Wilson was suspected of transmission of palm lethal decline in Tanzania because of PCR detection in insects from the field (Mpunami et al., 2000); however, once again, no positive transmissions were recorded.

The Auchenorrhyncha life cycle depends on a complex of factors, such as local humidity, temperature and photoperiod (Lohmann et al., 2010; Koji et al., 2012). The largest numbers of Auchenorrhyncha in the present study were captured in March and April in the dry-to-rainy season transition, corresponding to the period with the highest occurrence of $O$. sergipensis on coconut hybrids. This result is in agreement with another study showing that $O$. sergipensis population peaked on dwarf coconut accessions in Brazil in March and April 2016, indicating this species as being predominant in the dry-to-rainy season transition (Silva et al., 2018).

Among the climatic factors, the rainfall regime is one of the main factors for the distribution of insect populations. Seasonality in precipitation alters the availability of soil water and nutrients, eventually affecting plant development and increasing resources for insects (Araújo, 2013). The rainfall prior to March and April 2016 may have induced an increase in the development of undergrowth vegetation (grasses) between the tree rows and in the vicinity of the coconut hybrids, favouring better conditions for the nutrition of these palms and, consequently, for the Auchenorrhyncha development, mainly of cixiids, which reproduce on grass roots.

Most cixiid nymphs are considered to inhabit grass roots and the adults are mainly associated with coconut and other palm, whereas derbid nymphs feed on wood associated fungi and adults on monocotyledons, supposedly (Triplehorn \& Johnson, 2011). Possibly, the appearance of the $O$. sergipensis population in the dry season suggests that the eggs were laid during a humid period, favouring nymphal development and hatching.

Oecleus sergipensis was found on all coconut hybrids, particularly on parental red dwarf hybrids. Interestingly, the Auchenorrhyncha communities on the two MRD-derived hybrids were similar, as observed for the two BGDJ-derived hybrids. It is also noteworthy to see the high correlation of $O$. sergipensis individuals with MRD-derived hybrids. Silva et al. (2018) reported that this species was found on coconut accessions in living coconut genebanks, in the state of Sergipe, and captured in larger numbers on red dwarf coconut.

The present study contributes to the knowledge of the composition of the Auchenorrhyncha community found on coconut hybrids during contrasting periods (dry and wet) and this information could help in the establishment of control measures in the event that LY reaches Brazil.

Rainfall followed by coconut hybrids were found to be the factors with a major influence on the composition of the Auchenorrhyncha community. In general, potential vector species of phytoplasmas, O. sergipensis, Balclutha sp., Cenchreini sp., $O$. nigripennis and Cedusa sp. were found on coconut hybrids. The greatest abundance of Auchenorrhyncha was found on hybrid $\mathrm{BGD} \times \mathrm{BRT}$. Oecleus sergipensis was the only species with a high correlation between hybrids derived from the parent Malayan Red Dwarf, whereas the hybrid MYD $\times$ WAT provided the lowest abundance of this species. Unfortunately, both the MYD and the WAT are susceptible to LY. MYD was considered as a resistant variety (or at least, less susceptible than the 


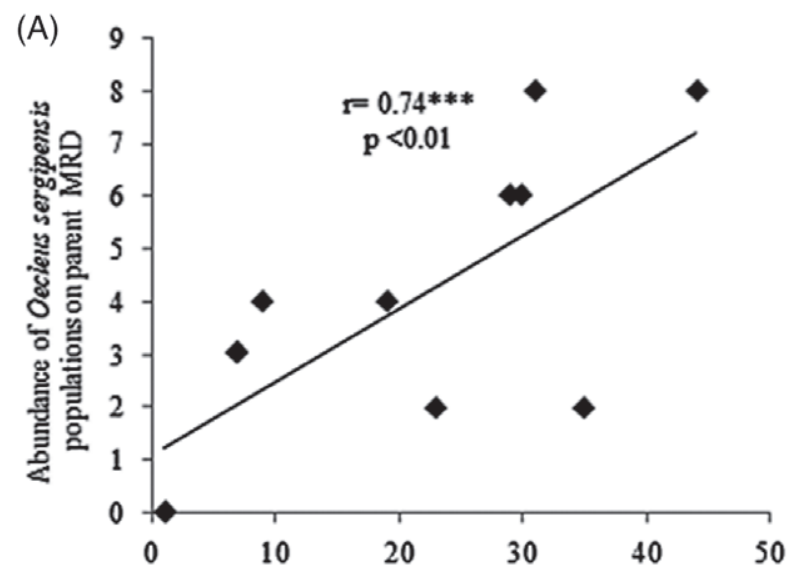

(C)

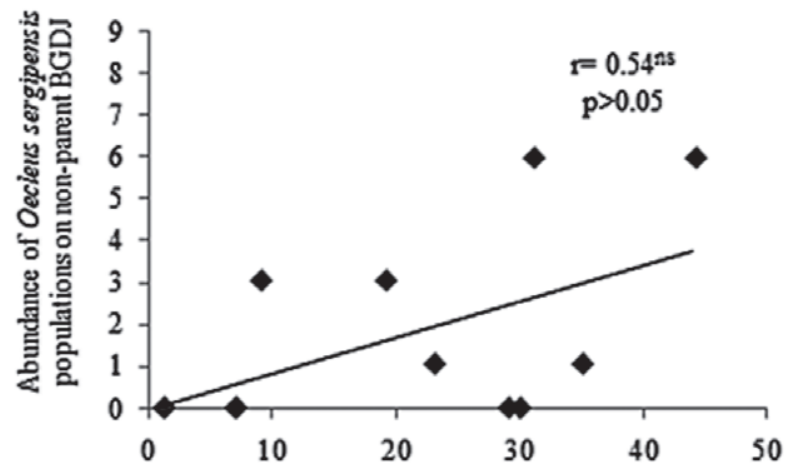

Abundance of Oecleus sergipensis populations on hybrids coconut MRD $\mathrm{x}$ VTT andMRD $\times$ TAG

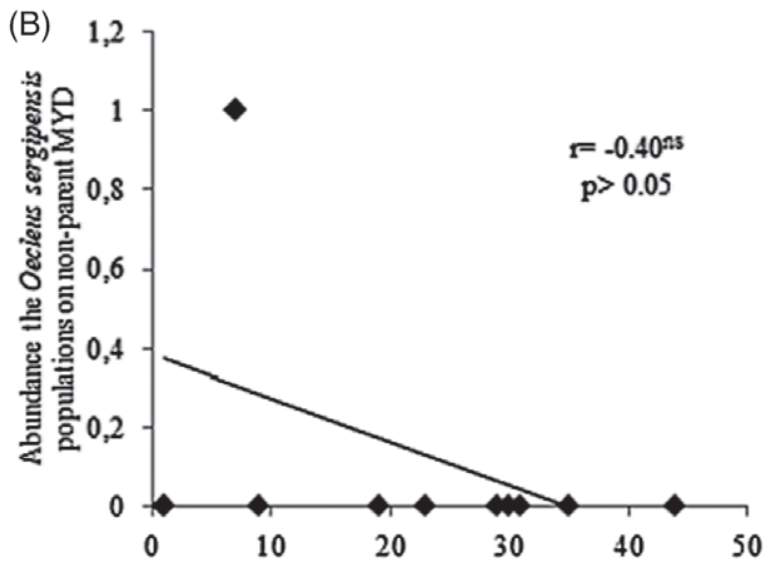

(D)

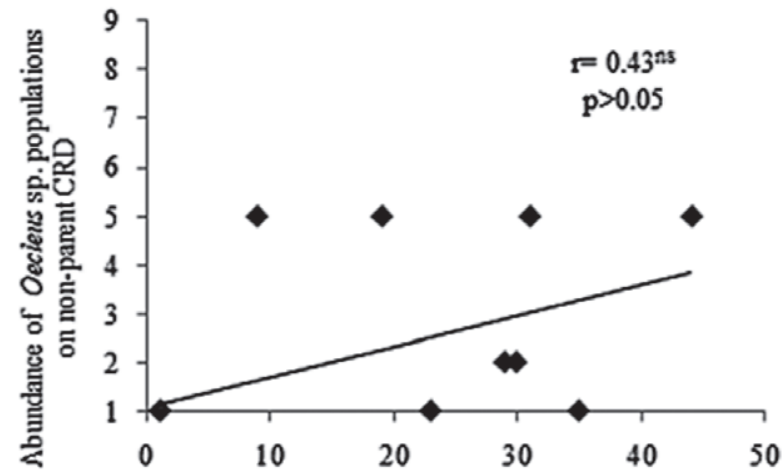

Abundance of Oecleus sergipensis populations on hybrids coconut MRD $\mathrm{x}$ VTT andMRD $\mathrm{x}$ TAG

Figure 2 Correlations between Oecleus sergipensis abundance on the hybrids MRD $\times$ VTT (Malayan red dwarf $\times$ Vanuatuan tall) and MRD $\times$ TAG (Malayan red dwarf $\times$ Tagnanan tall) with parental dwarf MRD (Malayan red) (A) and the nonparental dwarfs MYD (Malayan yellow) (B), BGDJ (Brazilian green) (C) and CRD (Cameroon red) (D). ns, not significant $(P<0.05)$.

others varieties grown in Jamaica) in the 1960/70s, although they were severely affected by LY in Jamaica and Florida in the late 1980s (Broschat et al., 2002; Lebrun et al., 2008). Information on Auchenorryncha communities should be used in breeding programmes for disease prevention and management of LY, in the event that it arrives in Brazil.

\section{Acknowledgements}

We thank Wilson Sampaio de Azevedo Filho and Luci Boa Nova Coelho for the identification of the Auchenorrhyncha. We also thank CAPES and CNPq for financial support.

\section{References}

Araújo, W.S. (2013) A importância de fatores temporais para a distribuição de insetos herbívoros em sistemas Neotropicais. Revista de Biologia, 1, 1-7.

Batugal, P., Konan, J.L., Sanaoussi, A., Kullaya, A., Tupinamba, E.A., Castilho, R. \& Been, B. (2005) Multilocation coconut hybrid trials in three African and three LAC countries. Coconut Genetic Resources (ed. by P. V. Batugal, R. Ramalha and J. Oliver). International Plant
Genetic Resources Institute - Regional Office for Asia, the Pacific and Oceania (IPGRI-APO), Serdang, Selangor DE, Malaysia.

Bartlett, C.R., Passos, E.M., Silva, F.G., Diniz, L.E.C. \& Dollet, M. (2018) A new species of Oecleus Stål (Hemiptera: Fulgoroidea: Cixiidae) from coconut in Brazil. Zootaxa, 4472, 358-364.

Breiman, L., Friedman, J.H., Olshen, R.A. \& Stone, C.G. (1984) Classification and regression tree. Wadsworth International Group, Belmont, CA.

Bressan, A., Holzinger, W.E., Nusillard, B., Sémétey, O., Gatineau, F., Simonato, M. \& Boudon-Padieu, E. (2009) Identification and biological traits of a planthopper from the genus Pentastiridius (Hemiptera: Cixiidae) adapted to an annual cropping rotation. European Journal of Entomology, 106, 405-413.

Broschat, T.K., Harrison, N.A. \& Donselman, H. (2002) Losses to Lethal Yellowing cast doubt on coconut cultivar resistance. Palms, 4, 186-189.

Brown, S.E., Been, B.O. \& Mclaughlin, W.A. (2006) Detection and variability of the lethal yellowing group (16Sr IV) phytoplasmas in the Cedusa sp. (Hemiptera: Auchenorrhyncha: Derbidae) in Jamaica. Annals of Applied Biology, 149, 53-62.

Celestino Filho, P., Louise, C. \& Lucchini, F. (1993) Estudos de transmissão do amarelecimento fatal do dendezeiro (Elaeis guineensis, Jacq), com insetos suspeitos. 194, Congresso Brasileiro fatal do dendezeiro', Vol. 14. Piracicaba. Anais, Piracicaba. 
Chen, W.Y., Huang, Y.C., Tsai, M.L. \& Lin, C.P. (2011) Detection and identification of a new phytoplasma associated with periwinkle leaf yellowing disease in Taiwan. Australasian Plant Pathology, 40, $76-48$.

Chuche, J., Danet, J.-L., Salar, P., Foissac, X. \& Thiéry, D. (2016) Transmission of 'Candidatus Phytoplasma solani' by Reptalus quinquecostatus (Hemiptera: Cixiidae). Annals of Applied Biology, 1, 1-10.

Cvrkovic, T., Jovic, J., Mitrovic, M., Krstic, O. \& Tosevski, I. (2014) Experimental and molecular evidence of Reptalus panzeri as a natural vector of bois noir. Plant Pathology, 63, 42-53.

Dakhil, H.A., Hammad, E.A.F., El-Mohtar, C. \& Abou-Jawdah, Y. (2011) Survey of leafhopper species in almond orchards infected with almond witches'-broom phytoplasma in Lebanon. Journal of Insect Science, 11, 60.

De'ath, G. (2002) Multivariate regression trees: a new technique for modeling species- environment relationships. Ecology, 83, 1105-1117.

Dollet, M., Quaicoe, R. \& Pilet, F. (2009) Review of coconut 'lethal yellowing' type diseases diversity, variability and diagnosis. Oilseeds and Fats, Crops and Lipids, 16, 97-101.

Dollet M., Llauger R., Fabre S., Julia, J.F., Gonzales C. \& Cueto J. (2010) Nymphocixia caribbea (Fennah) (Homoptera: Cixiidae) potential candidate as coconut lethal yellowing vector in the Carribean. In 'Proceedings Current status and perspectives of phytoplasma disease research and management. Cost Action FA087', p. 47, 1-2 February 2010. Sitges, Spain.

Dufrêne, M. \& Legendre, P. (1997) Species assemblages and indicator species: the need for a flexible assymetric approach. Ecological Monographs, 67, 345-366.

Edwin, B.T. \& Mohankumar, C. (2007a) Kerala wilt disease phytoplasma: phylogenetic analysis and identification of a vector, Proutista moesta. Physiological and Molecular Plant Pathology, 71, 41-47.

Edwin, B.T. \& Mohankumar, C. (2007b) Molecular identification of Proutista moesta as the vector and the phylogenetic analysis of KWD phytoplasma. Indian Journal of Biotechnology, 6, 560-563.

FAO - Food and Agriculture Organization (2017). Produção vegetal. [WWW document]. URL http://www.fao.org [accessed on 6 June 2017].

Flynn, J.E. \& Kramer, J.P. (1983) Taxonomic study of the planthopper genus Cedusa in the Americas (Homoptera: Fulgoroidea). Entomography, Vol. 2, pp. 121-260. USDA / ARS, Systematic Entomology Lab., IIBIII, U.S. National Museum of Natural History, Washington, D.C.

Grazia, J., Cavichioli, R.R., Wolff, V.R.S., Fernandes, J.A.M. \& Takiya, D.N. (2012) Hemiptera Linnaeus, 1758. Insetos do Brasil: Diversidade e Taxonomia, Vol. 1 (ed. by J. A. Rafael, G. A. R. Melo, C. J. B. Carvalho, S. A. Casari and R. Constantino), pp. 347-406. Holos Editora, Brasil.

Gurr, G.M., Johnson, A.C., Ash, G.J. et al. (2016) Coconut lethal yellowing diseases: a phytoplasma threat to palms of global economic and social significance. Frontiers in Plant Science, 7, 15-21.

Halbert, S.E., Wilson, S.W., Bextine, B. \& Youngblood, S.B. (2014) Potential planthopper vectors of palm phytoplasmas in Florida with a description of a new species of the genus Omolicna (Hemiptera: Fulgoroidea). Florida Entomologist, 97, 90-97.

Hanboonsong, Y., Ritthison, W., Choosai, C. \& Sirithorn, P. (2006) Transmission of sugarcane white leaf phytoplasma by Yamatotettix flavovittatus, a new leafhopper vector. Journal Economic Entomology, 99, 1531-1537.

Harrison, N.A., Davis, R.E., Oropeza, C. et al. (2014) 'Candidatus Phytoplasma palmicola', associated with a lethal yellowing-type disease of coconut (Cocos nucifera L.) in Mozambique. International Journal of Systematic and Evolutionary Microbiology, 64, 1890-1899.

Harrison, N.A., Helmick, E.E. \& Elliott, M.L. (2008) Lethal yellowing-type diseases of palms associated with phytoplasmas newly identified in Florida. Annals of Applied Biology., 153, 85-94.
Harrison, N.A., Myrie, W., Jones, P., Carpio, M.L., Castillo, M. \& Doyle, M.M. (2002) 16S rRNA interoperon sequence heterogeneity distinguishes strain populations of palm lethal yellowing phytoplasma in the Caribbean region. Annals of Applied Biology., 141, 183-193.

Howard, F.W., Norris, R.C. \& Thomas, D.L. (1983) Evidence of transmission of palm lethal yellowing agent by a planthopper, Myndus crudus (Homoptera: Cixiidae). Tropical Agriculture, 60, 168-171.

Koji, S., Midega, C.A.O., Hassan, M. \& Pickett, J. (2012) Seasonal abundance of Maiestas banda (Hemiptera: Cicadellidae) a vector of phytoplasma, and other leafhoppers and planthoppers (Hemiptera: Delphacidae) associated with Napier grass (Pennisetum purpureum) in Kenya. Journal of Pest Science, 85, 37-46.

Kramer, J.P. (1986) Supplement to a taxonomic study of the planthopper genus Cedusa in the Americas (Homoptera: Fulgoroidea: Derbidae). Entomography, 4, 245-314.

Lebrun, P., Baudouin, L., Myrie, W., Berger, A. \& Dollet, M. (2008) Recent lethal yellowing outbreak: why is the malayan yellow dwarf coconut no longer resistant in Jamaica? Tree Genetics and Genomes, 4, 125-131.

Lohmann, T.R., Pietrowski, V. \& Bressan, D.F. (2010) Flutuação populacional de cigarrinhas-das-pastagens na Região Oeste do Paraná. Semina: Ciências Agrárias, 1, 1291-1298.

Louise, C. (1990) Inventory of Homoptera and Heteroptera in relation to the amarelecimento fatal disease. In: 'Internationational seminar on the identification and control of the control of the organism (s) and/or other factor causing the spear rot syndrome in oil palm'. Proceedings Paramaribo, Suriname, pp. 36-46, 1998. Paramaribo, Suriname

Mathen, K., Solomom, J.J., Rajan, P. \& Oeetha, L. (1987) Electron microscopic evidence on the role of Stephanitis typica (Dist.) as a vector of coconut root (wilt) disease. Current Science, 56, 1339-1341.

Mathen, K., Rajan, P., Nair, C.P.R., Sasikala, M., Gunasekaran, M., Govindankutty, M. \& Solomom, J.J. (1990) Transmission of root (wilt) disease of coconut to coconut seedlings through Stephantis typica (Distant) (Heteroptera Tingidae). Tropical Agriculture (Trinidad), 67, 69-73.

McCoy, R.E., Howard, F.W., Tsai, J.H., Donselman, H.M., Thomas, D.L., Basham, H.G., Atilano, R.A., Eskafi, F.M., Britt, L.L. \& Collins, M.E. (1983) Lethal yellowing of palms. Agricultural experiment stations, institute of food and agricultural sciences. University of Florida, Gainesville. F. A. Wood, Dean for research. Bulletin 834 (RE McCoy, Ed.). 1-22.

McCune, B. \& Mefford, M.J. (2011) PC-ORD. Multivariate Analysis of Ecological Data. Version 6.0. MjM Software, Gleneden Beach, Oregon.

Melo, L.A.M.P., Michereff Filho, M., Benito, N.P., Oliveira, M.R.V. \& Cordeiro, L.A.M. (2008) Modelo determinístico para simular a dinâmica populacional de insetos com base no cálculo de graus-dia acumulados. Comunicado técnico, 1, 1-26.

Mpunami, A., Tymon, A., Jones, P. \& Dickinson, M.J. (2000) Identification of potential vectors of the coconut lethal disease phytoplasma. Plant Pathology, 49, 355-361.

Peel, M.C., Finlayson, B.L. \& Mcmahon, T.A. (2007) Updated world map of the Köppen-Geiger climate classification. Hydrology and Earth System Sciences, 11, 1633-1644.

Philippe, R.S., Reignard, S., Descamps, S. et al. (2009) Study on the transmission of coconut Lethal Yellowing in Ghana. Oilseeds \& fats Crops and Lipids, 16, 102-106.

Rajan, P. (2013) Transmission of coconut root (wilt) disease through planthopper, Proutista moesta Westwood (Homoptera:Derbidae). Pest Management in Horticultural Ecosystems, 17, 1-5.

Segarra-Carmona, A., Franqui, R.A. \& Otero-Arocho, M. (2013) Survey of palm-associated Fulgoroidea in Puerto Rico. Journal of Agriculture of the University of Puerto Rico, 97, 107-117.

Silva, F.G., Passos, E.M., Diniz, L.E.C., Farias, A.P., Teodoro, A.V., Fernandes, M.F. \& Dollet, M. (2018) Rainfall and coconut Accession 
explain the composition and abundance of the community of potential Auchenorrhyncha phytoplasma vectors in Brazil. Environmental Entomology, 47, 318-324.

Siqueira, L.A., Aragão, W.M. \& Tupinambá, E.A. (2002) A introdução do coqueiro no Brasil: Importância histórica e agronômica., Vol. 47. Documento: Embrapa Tabuleiros Costeiros, Brazil, 24p.

Triplehorn, C.A. \& Johnson, N.F. (2011) Estudo dos insetos_tradução da $7^{\mathrm{a}}$ edição de borror and delong's introduction to the study of insects. Cengage Learning, SP, Brazil.
Weintraub, P.G. \& Beanland, L. (2006) Insect vectors of phytoplasmas. Annual Review of Entomology, 51, 91-111.

Win, S.S., Muhamad, R., Ahmad, Z.A.M. \& Adam, N.A. (2011) Population fluctuations of Brown plant hopper Nilaparvata lugens Stal. and white backed plant hopper Sogatella furcifera Horvath on rice. Journal of Entomology, 2, 183-190.

Accepted 2 December 2018 